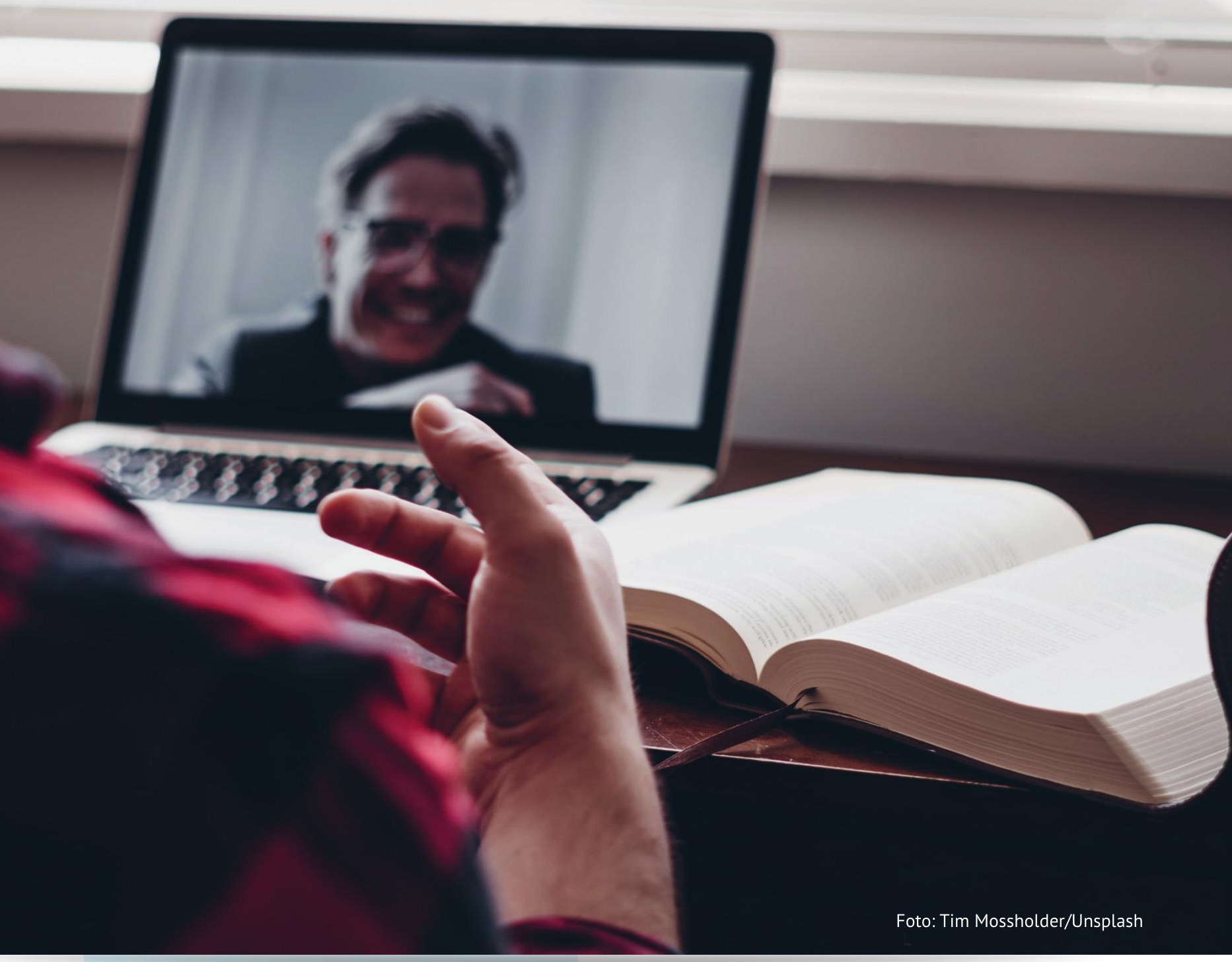

At udnytte digitaliseringen og de tilgængelige teknologiske muligheder til at skabe større kvalitet og værdi for vores brugere på en omkostningseffektiv måde er nøglen til digital transformation.

\title{
Skal vi snakke lidt om digital transformation?
}

Digital transformation handler om os selv som organisationer, men i høj grad også om vores brugere og de services, vi yder. Alle har vi lært en masse om at undervise og rådgive på Zoom og Skype i dette år.

Kom og del dine erfaringer på DFFU's årsmøde i september, hvor temaet er digital transformation. 


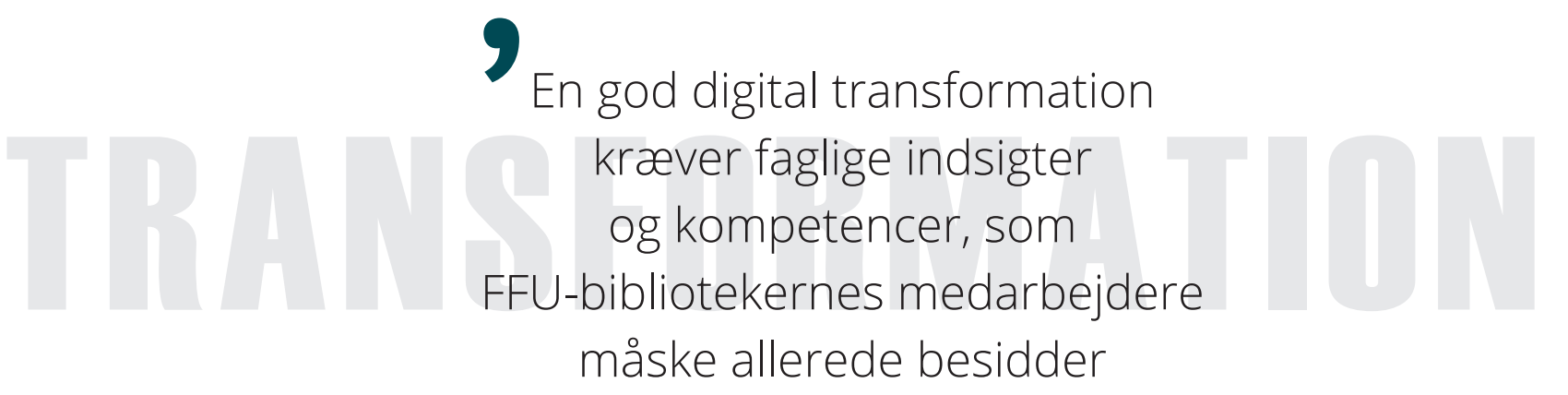

\section{BESTYRELSEN TAGER ORDET}

Vi har alle i vores arbejdsliv det seneste år været igennem en form for digital transformation.

Pludselig skulle vi finde ud af at samarbejde med vores kollegaer online. Undervise, vejlede, rådgive og være i kontakt med vores brugere online. Vi har lært mange nye værktøjer og omgangsformer på rekordtid, og det er lykkedes! Efterhånden som vi alle så småt vender tilbage til vores fysiske arbejdspladser, skal vi finde ud af, hvordan vi forener vores "gamle" arbejdsliv med de nye online kompetencer og erfaringer, vi har oparbejdet. Vi skal tage det gode fra vores online arbejdsliv med ind i vores fysiske arbejdsliv og forene de to, så det kommer os selv, vores organisationer og vores brugere til gavn.

\section{Brug for et helhedssyn}

Det bliver en omfattende og spændende proces og ingen af os kender alle de gode svar. Det kan derfor give mening, at vi snakker lidt om digital transformation. Men hvad betyder digital transformation egentlig og hvad kan vi bruge den til?
Pernille Kræmmergaard taler i sin bog: "Digital transformation - 10 evner din organisation skal mestre - og 3 som du har brug for" fra 2019, om digital transformation som noget andet og mere end digitalisering og brug af IT. Digital transformation er ikke blot at gøre noget elektronisk. At skabe digital transformation handler om at anlægge et helhedssyn på organisation, medarbejdere, brugere, samarbejdspartnere med flere.

\section{Kvalitet og værdi for brugerne}

Den digitale transformation handler om os selv som organisationer, men i høj grad også om vores brugere og de services, vi yder.

At udnytte digitaliseringen og de tilgængelige teknologiske muligheder til at skabe større kvalitet og værdi for vores brugere på en omkostningseffektiv måde er således nøglen til digital transformation.

Vi i FFU-bibliotekerne har ekspertisen og det digitale mindset inden for nogle af de aspekter, der definerer digital transformation.
Det har vi, fordi sektoren har været hurtig til at udnytte nye teknologier til aktiviteter som digitalisering, digital arkivering og digital problemløsning.

Men hvad kan digital transformation konkret betyde for FFU-bibliotekerne? Det er vi i DFFU-bestyrelsen nysgerrige på, og derfor sætter vi fokus på netop digital transformation på dette års årsmøde i september.

Digital transformation er ikke kun en ledelsesmæssig opgave, det er en proces, som alle skal bidrage til. En god digital transformation kræver faglige indsigter og kompetencer, som FFU-bibliotekernes medarbejdere måske allerede besidder.

Så kom og deltag i årsmødet, hvor vi sammen kan blive klogere på digital transformation og kan inspirere hinanden og ikke mindst dele viden og erfaringer.

Besøg også DFFU's facebook-side, hvor du finder en længere artikel om digital transformation. 